\title{
Specificity of the FTA-ABS and TPHA tests during pregnancy
}

\author{
W. MANIKOWSKA-LESIŃSKA, B. LINDA, AND W. ZAJAZC \\ From the Dermatological Clinic and Research Centre for Venereal Diseases, \\ Medical Academy, Bialystok, Poland
}

SUMMARY In order to determine whether pregnancy influences the specificity of the fluorescent treponemal antibody absorption (FTA-ABS) and Treponema pallidum haemagglutination assay (TPHA) tests, these tests, together with the quantitative fluorescent treponemal antibody (FTA) and Venereal Disease Research Laboratory (VDRL) tests, were carried out simultaneously on 2000 pregnant women who attended for compulsory prenatal screening. In only one patient $(0.05 \%$ of the total investigated) was a positive result to the TPHA test obtained, the specificity of which it was impossible to confirm. The FTA-ABS test gave a weakly reactive result of the borderline type but this was found to be non-specific in only four $(0.2 \%)$ patients. The results of our investigations showed that the specificity of the FTA-ABS and the TPHA tests performed on pregnant women did not differ from the specificity of these tests when carried out on other population groups.

\section{Introduction}

The problem of the specificity of the fluorescent treponemal antibody absorption (FTA-ABS) test and Treponema pallidum haemagglutination assay (TPHA) during pregnancy is of great practical significance since the FTA-ABS test has been widely used in verification procedures. In accordance with the recommendations of the United States Center for Disease Control (1976) screening for syphilis, including prophylactic tests on pregnant women, should be carried out by means of the Venereal Disease Research Laboratory (VDRL) technique. Where the screening test gives positive results verification is made by means of the FTAABS technique alone, the use of the Treponema pallidum immobilisation (TPI) test having been discontinued. The method recommended by the United States Center for Disease Control for the serological verification of syphilis is used in most other countries as well as the USA. In Poland, cases which are difficult to interpret are verified by means of the TPI test in addition to the FTA-ABS test.

Recently the TPHA test has been more widely

Address for reprints: W. Manikowska-Lesińka, Dermatological Clinic, Medical Academy, Manifestu Lipcowego 3, 15-879 Białystok, Poland

Received for publication 14 March 1978 applied as a confirmatory test instead of, or in addition to, the FTA-ABS because of the former's sensitivity and specificity. This method has been recommended for verification purposes by several authors, including Johnston (1972), Kiraly and Prerau (1974), Vaisman et al. (1974), Rudolph (1976), and Lesiński et al. (1977). Both the FTAABS and TPHA tests are known to possess considerable but not absolute specificity and may give non-specific positive results in comparatively few instances. Some authors (Buchanan and Haserick, 1970; Sparling, 1971; Meyer-Rohn, 1974; Cave and Nikitas, 1976) consider that pregnancy may be a cause of non-specific positive results of the FTA-ABS test. These reports, however, do not give sufficient evidence to show whether instances of non-specific positive FTA-ABS results are indeed noted more frequently in pregnant women than in the general population and, if so, whether this detracts from the value of the FTA-ABS technique in confirming reactive results of cardiolipin tests in pregnant women. In some recent reports (Shore, 1974; Kern, 1975; Meyer-Rohn, 1976) certain reservations have been expressed regarding the specificity of the TPHA test in pregnant women.

Our investigations were undertaken to study the specificity of both of the above treponemal tests in pregnant women and to determine their value as confirmatory tests for syphilis during pregnancy. 


\section{Material and methods}

The investigations were carried out on 2000 unselected pregnant women who were undergoing compulsory serological screening tests. The VDRL, TPHA, FTA-ABS, and quantitative FTA tests were carried out on the same samples of blood. In those patients in whom one of these tests gave a positive result the TPI test was also performed where technically possible.

The names of the patients with positive serological results were checked in our registers of patients who had been previously treated for syphilis. If the names of these patients were not found in the registers they were asked to report for a clinical examination and epidemiological inquiries.
The VDRL, FTA-ABS, FTA, and TPI tests were carried out by the methods routinely applied in Poland and described in detail by Lesiński et al. (1970). The TPHA test was carried out by means of the micromethod given by the suppliers of the reagents (Fujizoki Pharmaceutical Co. Ltd), as modified by Manikowska-Lesińska et al. (1975).

\section{Results}

The TPHA test gave positive results in $21(1.05 \%)$ patients, the FTA-ABS in $24(1.2 \%)$ (this includes 11 weakly reactive borderline type results), and the VDRL in only $10(0.5 \%)$ (Table 1). Of the 21 patients with positive results to the TPHA test, nine had positive results to the VDRL test and 20 positive results to the FTA-ABS test; seven of

Table 1 Results of the TPHA, FTA-ABS, and VDRL tests in 2000 pregnant women

\begin{tabular}{|c|c|c|c|c|c|c|c|}
\hline \multirow[b]{2}{*}{$T P H A$} & \multicolumn{2}{|c|}{$F T A-A B S$ positive } & \multicolumn{2}{|c|}{$F T A-A B S$ borderline } & \multicolumn{2}{|c|}{$F T A-A B S$ negative } & \multirow[b]{2}{*}{ Total } \\
\hline & $V D R L-$ & $V D R L+$ & $V D R L-$ & $V D R L+$ & $V D R L-$ & $V D R L+$ & \\
\hline $\begin{array}{l}\text { Positive } \\
\text { Negative } \\
\text { Total }\end{array}$ & $\begin{array}{l}8 \\
0 \\
8\end{array}$ & $\begin{array}{l}5 \\
0 \\
5\end{array}$ & $\begin{array}{l}3 \\
4 \dagger \\
7\end{array}$ & $\begin{array}{l}4 \\
0 \\
4\end{array}$ & $\begin{array}{l}1 * \\
1974 \\
1975\end{array}$ & $\begin{array}{l}0 \\
1 \ddagger \\
1\end{array}$ & $\begin{array}{r}21 \\
1979 \\
2000\end{array}$ \\
\hline
\end{tabular}

- Negative + Positive

* No history of syphilis

$\dagger$ Results of the borderline type obtained only on first testing

‡ Woman treated prophylactically because husband had primary syphilis

Table 2 Analysis of the results of serological and epidemiological investigations in 26 pregnant women with positive results to either the cardiolipin or treponemal tests

\begin{tabular}{|c|c|c|c|c|c|c|}
\hline Case No. & $V D R L$ & $T P H A$ & $F T A-A B S$ & $\begin{array}{l}\text { FTA } \\
\text { titre }\end{array}$ & $\begin{array}{l}\boldsymbol{T P I} \\
\%\end{array}$ & Case history \\
\hline $\begin{array}{r}1 \\
2 \\
3 \\
4 \\
5 \\
6 \\
7 \\
8 \\
9 \\
10 \\
11 \\
12 \\
13 \\
14 \\
15 \\
16 \\
17 \\
18 \\
19 \\
20 \\
21 \\
22 \\
23 \\
24 \\
25 \\
26\end{array}$ & $\begin{array}{l}+ \\
+ \\
+1- \\
+t+ \\
+\end{array}$ & 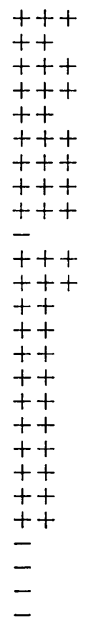 & $\begin{array}{l}\text { B } \\
\mathbf{B} \\
+++ \\
++ \\
\mathbf{B} \\
\mathbf{B} \\
++ \\
++ \\
+++ \\
+ \\
+++ \\
++ \\
++ \\
+++ \\
++ \\
++ \\
++ \\
\mathbf{B}^{+} \\
\text {B } \\
\mathbf{B}^{+} \\
++ \\
\mathbf{B}^{*} \\
\mathbf{B}^{*} \\
\mathbf{B}^{*} \\
\mathbf{B}^{*}\end{array}$ & $\begin{array}{r}450 \\
450 \\
1300 \\
2600 \\
300 \\
450 \\
1300 \\
1300 \\
2600 \\
- \\
4000 \\
1300 \\
1300 \\
450 \\
1300 \\
450 \\
2600 \\
450 \\
450 \\
450 \\
900 \\
- \\
450 \\
300 \\
150 \\
450\end{array}$ & $\begin{array}{r}80 \\
100 \\
50 \\
100 \\
100 \\
50 \\
0 \\
100 \\
80 \\
\mathrm{ND} \\
100 \\
100 \\
18 \\
0 \\
18 \\
55 \\
55 \\
0 \\
0 \\
0 \\
\mathrm{ND} \\
\mathrm{ND} \\
0 \\
0 \\
\mathrm{ND} \\
0\end{array}$ & $\begin{array}{l}\text { Treated early latent syphilis } \\
\text { Treated early latent syphilis } \\
\text { Treated late congenital syphilis } \\
\text { Treated early latent syphilis } \\
\text { Treated secondary syphilis } \\
\text { Treated secondary syphilis } \\
\text { Treated early latent syphilis } \\
\text { Treated secondary syphilis } \\
\text { Treated early latent syphilis } \\
\text { Prophylactic treatment } \\
\text { Treated secondary syphilis } \\
\text { Treated early latent syphilis } \\
\text { Treated early latent syphilis } \\
\text { Treated secondary syphilis } \\
\text { Treated secondary syphilis } \\
\text { Treated secondary syphilis } \\
\text { Treated early latent syphilis } \\
\text { Treated early latent syphilis } \\
\text { Treated early latent syphilis } \\
\text { Treated early latent syphilis } \\
\text { Insufficient information } \\
\text { Not possible to obtain history } \\
\text { No evidence of specific infection } \\
\text { No evidence of specific infection } \\
\text { No evidence of specific infection } \\
\text { No eivdence of specific infection }\end{array}$ \\
\hline
\end{tabular}

B Weakly reactive, borderline result

ND Not done

+ Weakly positive ++ Positive $t++$ Strongly positive - Negative

* Results of the borderline type obtained only on first testing 
these positive results were, however, of the weakly positive borderline type. In one patient only the TPHA test gave a positive result, whereas the VDRL and the FTA-ABS tests gave negative results. Out of 1979 patients with negative TPHA results, one had a positive VDRL test result, and four had isolated positive FTA-ABS results with a weak fluorescence of the borderline type.

A detailed analysis of the results of serological and epidemiological examinations carried out on 26 women, in whom at least one of the tests was positive, is shown in Table 2. In each of the nine patients with positive results to the VDRL and treponemal tests, it was found either from the history or from the files of the Central Register that the patient had been infected with syphilis and treated a few or several years previously. In one patient treated prophylactically because her husband was suffering from primary syphilis, only the VDRL test gave weakly positive results whereas the other tests gave negative results.

Of the 11 patients with negative results to the VDRL test but positive results to the TPHA and FTA-ABS tests, the history and records also showed previous syphilitic infection and treatment some years earlier. The FTA-ABS test gave weakly positive results of the borderline type in three of these 11 patients, and the TPI test gave positive or weakly positive results in only four. In one patient in whom both the TPHA and FTA-ABS tests gave positive results, and the FTA quantitative titre was $1 / 900$, the serological data indicated syphilitic infection although the history was inconclusive. On the other hand, in one patient with an isolated positive TPHA result it was not possible to obtain either clinical evidence or a case history.

In four patients in whom the FTA-ABS result was of the borderline type both the TPHA and VDRL tests gave negative results and neither clinical evidence nor history indicated previous syphilitic infection. When retested these sera also gave negative FTA-ABS and FTA results. In addition the TPI test carried out on three of these four patients gave negative results.

\section{Discussion}

In our study sera from four of the 2000 pregnant women examined gave weakly positive results of the borderline type to the FTA-ABS test but negative results on retesting, and these were probably non-specific. These patients comprised almost $0.2 \%$ of the total tested while all the other reactive or weakly reactive results to the FTA-ABS test were confirmed by the other serological tests or by the history and epidemiological evidence.
The problem of the poor reproducibility of the FTA-ABS test indicated by weak fluorescence of the borderline type has been the subject of numerous reports (Burns, 1975; Jaffe, 1975; Dans, 1976; Lesiński et al., 1977). Many of the poorly reproducible FTA-ABS results were found by these authors to be non-specific. Our investigations have shown that non-specific FTA-ABS results do not occur more frequently in women during pregnancy than in other groups.

As the data presented in Table 2 show, in only one of the 2000 pregnant women investigated did the TPHA test give a positive result, the specificity of which it was not possible to confirm; this comprised $0.5 \%$ of the total. Our results are in agreement with those of Young et al. (1974), who obtained identical results in their investigations on 1824 pregnant women, finding only one nonspecific positive TPHA result. West and Pagano (1972) found no non-specific positive results to the TPHA test carried out on 300 pregnant women. Sequeira and Eldrige (1973) found that the incidence of positive TPHA results in pregnant women did not exceed $0 \cdot 1 \%$, including very weakly reactive results (about $0.2 \%$ ). This percentage is not, therefore, higher than that of the non-specific results to the TPHA test found in investigations of other study groups by most European and Englishlanguage authors.

Findings which may raise doubts as to the specificity of the TPHA test in pregnant women were presented by Garner et al. (1973). These authors studied a group of 274 patients suspected of biologically false results to cardiolipin tests in whom $11.3 \%$ gave reactive results to the TPHA test. Eighty-two of these 274 patients were pregnant. In $12.2 \%$ of these women antibodies were also detected by the TPHA method. The investigations of Garner et al. (1973) were carried out on persons from areas with a high incidence of tropical diseases. In the opinion of Kiraly and Prerau (1974) this explains why the results of the former authors differ so essentially from the findings of European and English-speaking workers who are in agreement as to the high specificity of the TPHA test. As Fischman et al. (1974) indicated, the very small numbers of antibodies detected by the TPHA test, frequently because of its sensitivity, in tropical countries are only the residue of previous infection by endemic treponematosis.

Some explanation is needed for the fact that in our investigations not one case of untreated, active syphilis was found with either the cardiolipin or treponemal tests. This is due to the pronounced decrease in morbidity due to syphilis in Poland during the past few years. 
Our investigations have shown quite conclusively that neither the FTA-ABS test nor the TPHA test has a lower specificity in women during pregnancy and that these techniques can be used as reliable verification tests in pregnant women who have unexpectedly positive results to the cardiolipin tests used in screening procedures. If the FTA-ABS test used for confirmatory purposes gives borderline results the test should be repeated and supplemented by the TPHA test, or the TPI test, or both.

\section{References}

Buchanan, C. S., and Haserick, J. R. (1970). FTA-ABS test in pregnancy-a probable false-positive reaction. Archives of Dermato$\log y, 102,322-325$.

Burns, R. E. (1975). Spontaneous reversion of FTA-ABS test reactions. Journal of the American Medical Association, 235, 1424.

Cave, V. G., and Nikitas, J. A. (1976). Venereal disease: clinical and laboratory diagnoses. Mount Sinai Journal of Medicine, 43, 795-829.

Dans, P. E. (1976). FTA-ABS test. Journal of the American Medical Association, 235, 1424.

Fischman, A., Bree, A. D., Lynch, R. A. (1974). TPHA and RPL tests for yaws antibodies. British Journal of Venereal Diseases, 50 347-349.

Garner, M. F., Backhouse, J. L., Daskalopoulos, G., and Walsh, J. L. (1973). The Treponema pallidum haemagglutination (TPHA) test in biological false positive and leprosy sera. Journal Clinical Pathology, 26, 258-260.

Jaffe, H. W. (1975). The laboratory diagnosis of syphilis: new concepts. Annals of Internal Medicine, 83, 846-850.

Johnston, N. A. (1972). Treponema pallidum haemagglutination test for syphilis. Evaluation of a modified micro-method. British Journal of Venereal Diseases, 48, 474-478.

Kern, A. (1975). Serologische Gesamtdiagnostik der Syphilis (1975). Dermatologische Monatsschrift, 161, 905-917.
Kiraly, K., and Prerau, H. (1974). Evaluation of the Treponema pallidum haemagglutination (TPHA) test for syphilis on problem sera. Acta dermatovenereologica, 54, 303-310.

Lesiński, J., Miedzinski, F., and Towpik, J. (1970). Modern Syphilology. Polish State Medical Edition: Warsaw.

Lesiński, J., Nawara, A., Hryniewicka, I., Lyzwa, T., Kotyńska, J. (1977). Investigations on the specificity of the TPHA reaction in subject with suspected biologically false results of cardiolipin tes ${ }^{+}$ and its usefulness as a routine method of serological verification. Przeglad Dermatologiczny, 64, 441-446.

Manikowska-Lesińska, W., Linda, B., and Szymska, K. (1975). Studies on the method of the TPHA test. Przeglad Dermatologiczny, 62, 663-669.

Meyer Rohn, J. (1974). Unspezifisch positive reaktionen im FTATest. Hautarzt, 25, 528-529.

Meyer Rohn J. (1976). Moderne Syphilis Serologie. Zeitschrift für Hautkrankheiten, 51, 713-717.

Rudolph, A. H. (1976). The microhemagglutination assay for Treponema pallidum antibodies (MHA-TP). Journal of the American Venereal Diseases Association, 3, 3-8.

Sequeira, P. J. L., and Eldrige, A. E. (1973). Treponemal haemagglutination test. British Journal of Venereal Diseases, 49, 242-248.

Shore, R. N. (1974). Hemagglutination tests and related advances in serodiagnosis of syphilis. Archives of Dermatology, 109, 854-857.

Sparling, P. F. (1971). Diagnosis and treatment of syphilis. New England Journal of Medicine, 284, 642-653.

US Center for Disease Control (1976). Syphilis: CDC recommended treatment schedules. Journal of Infectious Diseases, 134, 97-99.

Vaisman, A., Paris-Hamelin, A., Fustec-Ibarboure, S., and Petit, V. (1974). La reaction d'hemagglutination passive pour le serodiagnostic de la syphilis (TPHA). II Results comparatifs entre la serologie classique, le test de Nelson et l'immunofluorescence sur 7000 serums humains. Médecine et Maladies Infectieuses, 4, 421-428.

West, B. S., and Pagano, D. A. (1972). Evaluation of the automated microhemagglutination assay for antibodies to Treponema pallidum. HSMHA Health Reports, 87, 93-96.

Young, H., Henrichsen, C., Robertson, D. H. H. (1974). Treponema pallidum haemagglutination test as a screening procedure for the diagnosis of syphilis. British Journal of Venereal Diseases, 50, 341-346. 